\section{"FORCIBLE REDUCTION OF POTT'S CURVATURE."}

To the Editors of THE LANCET.

SiRs, - With reference to an annotation upon this subject in THE LANCET of Sept. 11th, it is to be hoped that those interested in the subject will observe the proportion of deaths recorded. Three deatbs in thirteen cases, all within a week of the operation, is a large mortality, far exceeding that which occurs in treatment by careful fixation of the spine with general remedies. Forced extension without an anæsthetic carefully limited to the patient's powers of endurance is a far safer plan of treatment. It is one which I have been trying cautiously in a certain number of cases, and so far with good effects. For lateral curvature the forced reduction of the deformity promises, I think, excellent results. The patient should be placed upon a prone couch, the flat part of which should be long enough to support the whole length of the trunk. Then the surgeon standing over the patient is able to exert great power upon the projecting curves. It is of course necessary to keep up for a time, by mechanical means, the improvement made by manual force.

I am taking photographs of some cases treated in this manner in their different stages, so that $I$ shall have some definite illustrations to prove the results of the treatment, notes of which I hope, with your permission, to publish in THE LANCET at some future date.

$$
\text { I am, Sirs, yours faithfully, }
$$

Noble SMith.

Queen Anne-street, W., Sept. 13th, 1897.

\section{To the Eiditors of The LaNoET.}

SIRS,-In THE LANCET of Sept. 11th, at page 673, attention is drawn to the treatment of Pott's curvature by forcible reduction which has been recommended to the profession by Professor T. Jonnesco, of Bucharest. The annotation makes no mention of English writers in connexion with this treatment, which is described as "one of the most striking of the recent advances of surgery," although to them above all others is due the credit of the method; unfortunately, however, a long time has elapsed since the method was practised in England. The practice came to be abused, many patients dying under the forcible reduction. This abuse produced a pamphlet from Pott, which he dedicated to Dr. John Lewis Petit, one of the physicians to St. Bartholomew's Hospital. The brilliant successes attained by rest in spinal caries and the many fatalities by the old method in advanced cases stopped the practice. After Pott's death Sir James Earle put forward a plea for the resumption of forcible extension of the spine and pressure on the projecting knob in suitable cases; but he was as one crying in the wilderness. Pott's pathology of the disease had been approved by John Hunter, and succeeding generations swallowed both pathology, theory, and therapeutics without question until Lewis Sayre, of New York, re-introduced Earle's suspension head gear and a modernised form of his jacket. There were, however, in England surgeons at ali times who possessed sufficient courage to think for themselves, and although Pott's great and just influence stayed the progress of spinal surgery it did not wholly arrest it, for we read in Abernethy's lectures on local diseases, for the publication of which we are indebted to the courage and enterprise of the Founder of THE LANCET, that in certain cases he recommended cutting down on the projecting spine. Abernethy thus describes the incident in his professional experience: "And it was proposed as a question, Could anything be done in this case? I said, 'I cannot tell you, except taking out the rings of the vertebræ.' But that was considered so hard an operation that it was not at all contemplated. ...... Yet such a thing has been done, and done in London, and at the very time this accident happened."

Dublin, Sept. 14th, 1897. I am, Sirs, yours truly, GEORGE FoY.

\section{THE LATE DR. BRAXTON HICKS. $T$, the Editors of THE LANCET.}

SIRS, - A very important omission occurs in your notice of the late $D_{r}$. Braxton Hicks in the matter of his discovery of the rhythmical movements of the aterus in pregnancy. I am writing away from all books of reference, but I think I am correct in saying that he discovered and established the point completely in his own work. The discovery lay for years neglected till $I$ pointed out that it is by far the most trustworthy of all the signs of pregnancy. Even now it does not receive the prominence from writers of text-books which its value deserves.

Llandudno, Sept. 11th, 1897. I am, Sirs, yours faithfully, LAWSON TAIT.

\section{INFAN'T INCUBATORS.}

\section{To the puditors of THW LANOET.}

SIRS,-In the interests of the general public we desire to call your attention to the fact that the success of our Infant Incubator Institution at the Victorian Era Exbibition at Earl's Court has attracted the notice of unscrupulous imitators. We are informed, for example, that various persons are calling upon, and writing to, members of the medical profession, hospitals, infirmaries, \&c., asking for their support, and falsely representing that they are opening branch institutions in connexion with us, and asking for the loan of children to experiment with.

We consider, under these circumstances, that it is our duty to warn members of the medical profession, also nurses, parents, and all publis institutions, not to entrust their children to any applicants whatsoever without first taking every precaution to assure themselves that they will not be made the victims of showmen, as well as of inexperienced and irresponsible persons who seek to trade upon the establisbed reputation of an invention that has been recognised by both the medical and the lay press.

The institution at Earl's Court is the first of its kind in England, and we have not made any arrangements, nor have we given anyone anthority to further exhibit, at any exhibition or place of public resort in the United Kingdom, so that all persons, no matter what their credentials may seem to be, making application for space and intimating that they have the power to exhibit Mr. Paul Altmann's invention should be classed as impostors.

$$
\text { We are, Sirs, yours obediently, }
$$

SAMUEL SCHENKEIN,

Earl's-court, S.W., Sept. 8th, $1897 . \quad$ MARTIN CONEY.

\section{"IS 'MEDICAL DEFENCE' DEROGATORY} TO THE DIGNITY OF MEDICAL MEN?"

\section{To the Hditors of THE LANOET.}

SIRS,-It is to be hoped that the thoughtful and temperate letter of "Registered Practitioner" in THw LANCET of Sept. 4th has attracted the attention of the profession. There is no doubt that our governing bodies, from the General Medical Council downwards, do consider that the defence of the practitioner is derogatory to their dignity. The reason for this is plainly owing to the composition of these bodies and to their non-representative character. If it could be brought home to the eminent men who direct the policy of our councils and corporations that by a more liberal course of action they could do much to ameliorate the lot of thousands of their less fortunate confrères, I feel sure that they would not consider such action derogatory. Your exhaustive series of articles on the "Battle of the Clubs" give an idea of the pecuniary loss which the profession is suffering all over the country owing to abuses which are perfectly remediable if our governing bodies were willing to take them in hand. It is to be hoped that those suffering from these abuses will lose no opportunity of pressing them on the attention of the powers that be until their extent is fully realised. Doubtless the promotion of the scientific progress of our profession is all important, but surely the protection of the material interest of those who practise it is at least equally so.

Sept. 13th, 1897. I remain, Sirs, yours faithfally,

W. G. D.

WE have received from the Volunteer Ambulance School the syllabus of courses of instruction of the classes for the training of stretcher bearers, to be held at the beadquarters of the London Rifle Brigade, 130, Bunhill-row, E.C., commencing at 7.30 p.m., on Monday, Oct. 4th, 1897 . Surgeon-Major H. F. Stokes, of the London Rifle Brigade, the Senior Medical Officer Instructor, appears to have taken every precaution to make the course a thorough one. 